\title{
EDITORIAL
}

\section{Cervical cancer. The case of Mexico}

Cervical CANCER Remains as ONE OF THE BIgGeST KILLERS IN WOMEN AROUND THE WORLD. ACCORDING TO THE GLOBOCAN 2000, IT IS ESTIMATED THAT IN THE YEAR 2000, THERE WERE 470,606 NEW CASES AND 233,372 DEATHS'. SADLY, THIS IS HAPPENING WHEN THE MORTALITY FOR THIS NEOPLASIA HAS DRAMATICALLY DROPPED IN COUNTRIES WITH HIGH STANDARDS OF LIVING AS A CONSEQUENCE OF EARLY DETECTION. IN THIS LATTER SITUATION, MOST CASES ARE DETECTED IN EARLY STAGES AND CAN BE CURED WITH LOCAL THERAPIES. ON THE CONTRARY, IN WOMEN FROM COUNTRIES LACKING ORGANIZED AND EFFECTIVE SCREENING PROGRAMS AS WELL AS IN A SUBSET OF WOMEN FROM HEALTHIER COUNTRIES MOST CASES ARE DIAGNOSED LATE ON THE COURSE OF DISEASE (FIGO STAGES IB2 TO IVA) AND THEIR TREATMENT REPRESENT A FORMIDABLE CHALLENGE LIKE ANY CANCER DIAGNOSED IN ADVANCED STAGE.

The SURVIVAL PROBABILITIES FOR CANCER PATIENTS HAS STEADLY INCREASING IN THE LAST DECADES AS A CONSEQUENCE OF IMPROVEMENTS IN SURGICAL AND RADIOTHERAPEUTIC TECHNIQUES AS WELL AS THE AVAILABILITY OF MORE ACTIVE CHEMOTHERAPY AGENTS, BUT MOST IMPORTANTLY, DUE TO THE MULTIDISCIPLINARY CONCEPT OF TREATMENT THAT INCORPORATES THESE MODALITIES ${ }^{2}$. SuRPRISINGLY, THE TREATMENT OF LOCALLY ADVANCED CERVICAL CANCER HAD EXPERIENCED NO MAJOR CHANGES FOR ALMOST 80 YEARS WHERE EXCLUSIVE RADIATION HAS BEEN CONSIDERED THE STANDARD OF CARE, THUS, 5YEAR SURVIVAL FOR STAGES IB, IIB, IIIB AND IVA ARE $72.2 \%, 63.7 \%, 41.7 \% 16.4 \%$ ACCORDING THE 1998 ANNUAL Report on the Results of Treatment in GynaecoLOgical Cancer ${ }^{3}$. The long PERManence of THIS UNIMODAL TREATMENT WAS PARTIALLY DUE TO THE CLASSICAL CONCEPT THAT CERVICAL CANCER WAS A DISEASE THAT PROGRESSES IN AN ORDERLY FASHION (LOCAL, THEN REGIONAL AND AT THE VERY LAST SYSTEMICALLY) AND, THEREFORE, COULD BE EFFECTIVELY TREATED WITH a local MOdality SUCH as Radiation. NeVERTHeless, SINCE THE EARLY EIGHTIES, CLINICAL TRIALS OF CHEMOTHERAPY FOLLOWED BY RADIATION WERE PERFORMED YIELDING NO BETTER RESULTS THAN RADIATION ALONE, WHICH WAS CONFIRMED IN A RECENT METAANALYSIS 4 . ON THE OTHER HAND, CLINICAL TRIALS HAVE BEEN PERFORMED WITH NEOADJUVANT CHEMOTHERAPY FOLLOWED BY RADICAL SURGERY, AND IN OPOSITION TO THE RESULTS OF NEOADJUVANT THERAPY FOLLOWED BY
RADIATION, THIS MODALITY HAS PROVEN TO BE BENEFICIAL WHICH WAS CONFIRMED IN ANOTHER RECENT METAANALYSIS THAT HAS SHOWN AN ABSOLUT BENEFIT IN 5YEAR SURVIVAL OF $15 \% 0^{5}$. NEVERTHELESS, SUCH EVIDENCE HAS NOT BEEN UNIVERSALLY ACCEPTED SO THAT NEOADJUVANT CHEMOTHERAPY REMAINS AS AN EXPERIMENTAL THERAPY.

BETWEEN THE YEARS 1999 AND 2000 FIVE RANDOMIZED TRIALS THAT COMPARED CONCURRENT RADIATION WITH CISPLATIN OR CISPLATIN/5-FU VERSUS RADIATION ALONE WERE PUBLISHED ${ }^{6-10}$. THESE STUDIES ACCRUED ALMOST 2000 PATIENTS AND SHOWED A REDUCTION ON RISK OF DEATH BETWEEN $30 \%$ TO 50\% IN THE COMBINED ARM, LEAding to the National Cancer Institute of the US TO ISSUE A STRONG RECOMMENDATION FOR ADDING CISPLATIN-BASED THERAPY TO ALL PATIENTS WHO REQUIRE RADIATION FOR THE TREATMENT OF THIS TUMOR. More RECENTLY, TWO ADDITIONAL PHASE III RANDOMIZED TRIALS OF CHEMORADIATION USING EPIRUBICIN" AND MITOMYCIN $\mathrm{C}^{12}$ CONFIRMED A SURVIVAL ADVANTAGE OVER RADIATION ALONE. ODDLY ENOUGH, IN THE LAST RANDOMIZED TRIAL REPORTED ${ }^{15}$, INVESTIGATORS FROM CANADA FOUND NO DIFFERENCES IN SURVIVAL IN PATIENTS WHO RECEIVED CISPLATIN/RADIATION OR RADIATION ALONE. NEVERTHELESS, IN THE EDITORIAL THAT ACCOMPANIED THE PUBLICATION OF THAT STUDY, Rose and Bundy POOLED THE RESUlts From the SIX STUDIES OF CISPLATIN-BASED CHEMORADIATION COMING TO THE CONCLUSION THAT A STRONG REDUCTION IN THE RISK OF DEATH WAS STILL SEEN ${ }^{14}$. THUS, AFTER SEVERAL DECADES OF «RADIATION MONOTHERAPY» THE CONCURRENT APPROACH HAS BECOME THE STANDARD OF CARE FOR PATIENTS WITH LOCALLY ADVANCED CERVICAL CANCER.

NONETHELESS, THE CURRENT TREATMENT IS FAR TO BE THE OPTIMAL. IN SEPTEMBER 2001, A META-ANALYSIS OF LITERATURE HAS UNDERSCORED THAT THIS TREATMENT YIELDS ONLY A 12\% OF ABSOLUTE IMPROVEMENT IN SURVIVAL $^{15}$ WHICH CLEARLY CALLS FOR TESTING NEW MODALITIES IN ORDER TO IMPROVE THESE RESULTS.

Cervical cancer in Mexico remains a serious proBLEM WITH MORTALITY APPROACHING 13 PER 100,000 INHABITANTS. UNFORTUNATELY, AROUND 70\% OF THE PATIENTS ARE DIAGNOSED IN LOCALLY ADVANCED STAGES ${ }^{16}$. HeNCE IN OUR INSTITUTION WE ARE ACTIVELY TRYiNg SEVERAL THERAPEUTIC APPROACHES AIMING AT IMPROVING 
THE RESUlts of treatment. EARLy EFForts WERE FOCUSED ON REDUCING THE ACUTE AND CHRONIC RADIATION-ASSOCIATED MORBIDITY WITH THE USE OF THE RADIOPROTECTANT AMIFOSTINE ${ }^{17}$ AS WELL AS TO THE USE OF ALFA-INTERFERON CONCURRENT WITH PELVIC RADIATION AS A RADIOSENSITIZER ${ }^{18}$. THIS LATTER APPROACH, YET EFFECTIVE, WAS TOO TOXIC TO BE FURTHER PURSUED. WE HAVE ALSO TESTED HIGH-DOSE CHEMOTHERAPY IN HIGHRISK PATIENTS IN AN ADJUVANT SETTING. IN A PILOT STUDY THREE PATIENTS IN WHOM THE SURGICAL SPECIMEN DEMONSTRATED A HIGH NUMBER OF PELVIC LYMPH NODES INVOLVED WERE TREATED WITH THE ICE (IFOSFAMIDE, CARBoplatin, ETOPOSIDE) PROGRAM SUPPORTED BY PERIPHERAL BLOOD TRASPLANT. AT MORE THAN FIVE YEARS OF FOLLOW-UP NONE OF THESE PATIENTS HAS RELAPSED ${ }^{19}$. WE HAVE ALSO STUDIED IMMUNOTHERAPY, TESTING THE CONCEPT OF IMMUNORESTORATION AND CONTRASUPPRESSION BY THE USE OF A MIXTURE OF NATURAL CYTOKINES, ZINC AND NONSTEROIDAL ANTIINFLAMMATORIES ${ }^{20}$. FUTURE STUDIES ON IMMUNOTHERAPY ARE IN THE PHASE OF PLANNING. More RECENTLy, BEFore the RESUlts OF CONCURRENT CHEMORADIATION WERE REPORTED, WE INITIATED A SERIES OF PHASE II STUDIES OF NEOADJUVANT CHEMOTHERAPY IN LOCALLY ADVANCED PATIENTS (FIGO STAGES IB2-IIIB) FOLLOWED BY SURGERY. IN THE FIRST ONE, A COMBINATION OF CISPLATIN AND GEMCITABINE WAS USED FOR THREE COURSES IN 41 PATIENTS, OBTAINING AN OVERALL RESPONSE RATE OF 95\% ${ }^{21}$. INTERESTINGLY, IN 6 OUT OF $23 \quad(26 \%)$ PATIENTS THAT UNDERWENT RADICAL SURGERY, A PATHOLOGICAL COMPLETE RESPONSE WAS SEEN ${ }^{22}$. BECAUSE IT HAS BEEN SHOWN THAT PATIENTS THAT HAVE A SUBOPTIMAL RESPONSE OR DO NOT RESPOND TO CHEMOTHERAPY AND CAN NOT BE OPERATED DO POORLY WITH RADIATION, WE USED RADIATION CONCURRENT WITH WEEKLY CISPLATIN TO COMPLETE THE TREATMENT. THIS KIND OF «CONSOLIDATION» PROVED TO BE FEASIBLE AND EFFECTIVE ${ }^{25}$. SIMILAR RESUlTS WERE OBTAINED IN ANOTHER SMALL STUDY USING THE COMBINATION OF OXALIPLATIN GEMCITABINE AS INDUCTION THERAPY FOLLOWED BY EITHER SURGERY OR CONCURRENT CISPLATIN RADIATION ${ }^{24}$. BECAUSE THE RESULTS OF TRIALS OF NEOADJUVANT CHEMOTHERAPY HAVE SHOWN THAT PATIENTS WHO CAN UNDERGO SURGERY DO BETTER THAN THOSE WHO CAN NOT, IN A RECENTLY COMPLETED PHASE II TRIAL USING THE COMBINATION OF CARBOPLATIN PACLITAXEL WE DECIDED TO PUT AN EXTRA EFFORT TO OPERATE TO ALL PATIENTS REGARDLESS OF THE RESPONSE TO THE INDUCTION CHEMOTHERAPY AS LONG AS THEY DO NOT PROGRESS TO CHEMOTHERAPY. IN SUCH TRIAL OF 43 PATIENTS ALL BUT TWO WERE TAKEN TO SURGERY, AND IN ADDITION, ADJUVANT CHEMORADIATION WAS ADMINISTERED TO ALL PATIENTS WHO HAD NO PATHOLOGICAL COMPLETE RESPONSE. THE RESULTS OF THIS TRIPLE MODALITY SEEM ENCOURAGING BUT IS TOO EARLY TO COME TO DEFINITIVE CONCLUSIONS (SUBMITTED).

THE LAST OF THE RANDOMIZED TRIALS COMPARING NEOADJUVANT CHEMOTHERAPY FOLLOWED BY SURGERY VER-
SUS RADIATION ALONE WAS REPORTED IN THIS YEAR ${ }^{25}$. THESE RESULTS SHOWED THE SUPERIORITY OF THE NEOADJUVANT CHEMOTHERAPY SURGERY APPPROACH, HOWEVER, THEY APPEARED WHEN THE CONTROL ARM (RADIATION ALONE) IS NOT THE CURRENT STANDARD FO TREATMENT, HENCE THE VALUE OF THIS NEOADJUVANT MODALITY HAS TO BE NOW COMPARED TO STANDARD Chemoradiation. Currently, a MUlticentric Study FROM THE EORTC IS ONGOING TO DEFINE THIS ISSUE. WE HAVE RECENTLY REPORTED A COMPARISON OF OUR INITIAL STUDY OF NEOADJUVANT CISPLATIN GEMCITABINE FOLLOWED BY SURGERY VERSUS WEEKLY CISPLATIN CONCURRENT WITH PELVIC RADIATION. DESPITE BEING A NONRANDOMIZED COMPARISON, BOTH STUDY GROUPS WERE WELL-BALANCED FOR THE MOST RELEVANT CLINICOPATHOLOGICAL CHARACTERISTICS. INTERESTINGLY, AT A MEDIAN FOLLOW-UP OF ALMOST THREE YEARS, THERE ARE NO DIFFERENCES IN TERMS OF SURVIVAL ${ }^{26}$. MOREOVER, BOTH TREATMENT APPROACHES WERE, AS EXPECTED, SUPERIOR TO RADIATION ALONE ${ }^{27}$. BECAUSE THIS PRELIMINARY EVIDENCE SUGGESTS THAT EITHER NEOADJUVANT CHEMOTHERAPY SURGERY AND RADIATION CONCURRRENT WITH CISPLATIN WILL YIELD EQUIVALENT RESULTS ON TERMS OF SURVIVAL, WE ARE CURRENTLY TESTING TWO TREATMENT APPROACHES. ON ONE HAND, WE ARE TESTING NEOADJUVANT OR PREOPERATIVE CHEMORADIATION WITH CISPLATIN VERSUS CISPLATIN GEMCITABINE DURING EXTERNAL RADIATION. AT THE COMPLETION OF EXTERNAL RADIATION INSTEAD OF BRACHYTHERAPY, THE PATIENTS ARE TAKEN TO RADICAL HYSTERECTOMY. SO FAR, IN THE FIRST 20 PATIENTS WHO HAVE COMPLETED ALL TREATMENT, THE PATHOLOGICAL OR NEAR-COMPLETE PATHOLOGICAL COMPLETE RESPONSE RATE EXCEEDS 70\%. IT IS WELL-KNOWN THAT ONE OF THE MOST IMPORTANT PROGNOSTIC FACTORS FOR ANY TRIAL OF INDUCTION THERAPY IS THE ACHIEVEMENT OF COMPLETE PATHOLOGICAL COMPLETE RESPONSE, HENCE, WE ARE EXPECTING TO OBSERVE A FAVORABLE SURVIVAL WITH THIS MODALITY. ON THE OTHER HAND, PRECLINICAL ${ }^{28}$ AND CLINICAL ${ }^{29}$ STUDIES HAVE SHOWED THE POTENT RADIOSENSITIZING EFFECT OF GEMCITABINE EITHER ALONE OR IN COMBINATION WITH CISPLATIN IN CERVICAL CANCER HENCE, WE, ALONG WITH ANOTHER NINE INSTITUTIONS FROM LATIN AMERICa, Asia and East Europe Will begin in this year a RANDOMIZED STUDY OF THE STANDARD CISPLATIN CHEMORADIATION VERSUS CISPLATIN GEMCITABINE CHEMORADIATION FOLLOWED BY TWO ADJUVANT COURSES OF Cisplatin gemCitabine. Finally, WE EXPECT to BEgiN A COUPLE OF STUdies OF MOLECUlar TARgETED THERAPY SHORTLY.

These ACTIONS AIMED TO REDUCE THE MORTALITY FOR CERVICAL CANCER WOULD NOT HAVE MUCH SENSE WITHOUT DIRECTING AN EVEN BIGGER EFFORT TO EARLIER DETECTION. OUR NATIONAL SCREENING PROgRAM HAS RECENTLY BEEN RE-ESTRUC- TURED AND WE ARE EAGERLY WAITING TO SEE IN THE NEXT FEW YEARS A DROP IN CERVICAL CANCER MORTALITY. 


\section{REFERENCES}

1. Parkin DM, Bray F, Ferlay J, Pisani P. Estimating the WORLD CANCER BURDEN: GLOBOCAN 2000. INT J CANCER 2001;94: 153-6.

2. Greenlee RT, Hill-Harmon mb, Murray T, Thun M. Cancer statistics, 2001. CA Cancer J Clin 2001;51:15-36.

3. Annual Report on the Results of Treatment in Gynaecological Cancer. J Epidemiol Statist 1998;3:5-34.

4. Tierney JF, Stewart La. Neoadjuvant chemotherapy FOLLOWED BY RADIOTHERAPY FOR LOCALLY ADVANCED CERVIX CANCER: A META-ANALYSIS USING INDIVIDUAL PATIENT DATA FROM RANDOMISED CONTROLLED TRIALS (ABSTRACT 824). Procc ASCO 2002; 21:207A.

5. Stewart La, Tiernay JF. Neoadjuvant chemotherapy AND SURGERY VERSUS STANDARD RADIOTHERAPY FOR LOCALLY ADVANCED CERVICAL CANCER: A META-ANALYSIS USING INDIVIDUAL PATIENT DATA FROM RANDOMISED CONtrolled trials (abstract 825). Proce ASCO 2002;21:207A.

6. Peters WA zRD, Liu PY, Barrett R, et al. Concurrent CHEMOTHERAPY AND PELVIC RADIATION THERAPY COMPARED WITH PELVIC RADIATION THERAPY ALONE AS ADJUVANT THERAPY AFTER RADICAL SURGERY IN HIGH-RISK EARLYSTAGE CANCER OF THE CERVIX. J CLIN ONCOL 2000;18:16o613.

7. Morris M, Eifel PJ, Lu J, et al. Pelvic radiation with CONCURRENT CHEMOTHERAPY COMPARED WITH PELVIC AND PARA-AORTIC RADIATION FOR HIGH-RISK CERVICAL CANCER. N ENGL J MED 1999; 340:1137-43.

8. Keys HM, Bundy BN, Stehman FB, et al. A comparison OF WEEKLY CISPLATIN DURING RADIATION THERAPY VERSUS IRRADIATION ALONE EACH FOLLOWED BY ADJUVANT HYSTERECTOMY IN BULKY STAGE IB CERVICAL CARCINOMA: A RANDOMized trial of THE Gynecology Oncology Group. N ENGL J MED 1999;340: 1154-61.

9. Rose PG, Bundy BN, Watkins EB, et al. Concurrent CISPLATIN-BASED CHEMORADIATION IMPROVES PROGRESSION-FREE SURVIVAL IN ADVANCED CERVICAL CANCER: RESults of a RANDOMized Gynecologic Oncology Group STUDY. N ENGL J MED 1999;340:1144-53.

10. Whitney CW, Sause W, Bundy BN, et al. A randomized COMPARISON OF FLUOROURACIL PLUS CISPLATIN VERSUS HYDROXYUREA AS AN ADJUNCT TO RADIATION THERAPY IN STAGES IIB-IVA CARCINOMA OF THE CERVIX WITH NEGATIVE PARA-AORTIC LYMPH NODES. A GYNECOLOGIC ONCOLOGY Group and Southwest Oncology Group Study. J Clin ONCOL 1999;17:1339-48.

11. Wong LC, Ngan HYS, Cheung ANY, et al. ChemoradiaTION AND ADJUVANT CHEMOTHERAPY IN CERVICAL CANCER. J Clin ONCOL 1999;17:2055-60.

12. Roberts KB, Urdaneta N, Vera R, et al. Interim reSULTS OF A RANDOMIZED TRIAL OF MITOMYCIN C AS AN ADJUNT TO RADICAL RADIOTHERAPY IN THE TREATMENT OF LOCALLY ADVANCED SQUAMOUS-CELL CARCINOMA OF THE CERVIX. INT J CANCER 2000;90:206-23.

13. Pearcey R, Brundage M, Drouin P, et al. Phase III TRIAL COMPARING RADICAL RADIOTHERAPY WITH AND AND WITHOUT CISPLATIN CHEMOTHERAPY IN PATIENTS WITH ADVANCED SQUAMOUS CELl CANCER OF THE AERViX. J CliN ONCOL 2002;20: 966-72.

14. Rose PG, Bundy BN. Chemoradiation for locally aDVANCED CERVICAL CANCER: DOES IT HELP? J CliN ONCOL. 2002;20:891-3.

15. Green Ja, Kirwan JM, Tierney JF, et al. Survival and RECURRENCE AFTER CONCOMITANT CHEMOTHERAPY AND RADIOTHERAPY FOR CANCER OF THE UTERINE CERVIX: A SYSTEMATIC REVIEW AND META-ANALYSIS. LANCET 2001;358:781-6.
16. Mohar A, Frias-Mendivil M. Epidemiology of CerviCAL CANCER. CANCER INVEST 2000;18:584-90.

17. Gallardo D, Mohar a, Calderillo G, et al.Cisplatin, RADIATION, AND AMIFOSTINE IN CARCINOMA OF THE UTERINE CERViX. InT J Gynecol CANCER 1999;9:225-30

18. Verastegui-Avilés E, Mohar A, Mota A, Guadarrama A, DE la Garza-Salazar J. Combination of radiation theRAPY AND INTERFERON ALPHA-2B IN PATIENTS WITH ADVANCED CERVICAL CARCINOMA: A PILOT STUDY. INT J GyNECOL CANCER 1999;9: 401-5.

19. Dueñas González A, Lara Medina F, Solorza luna G, Mota García A, de la Garza Salazar J, Sobrevilla Calvo P. AdjuVant high-Dose Chemotherapy SuPPorTED BY PERIPHERAL BLOOD STEM CELL TRANSPLANTATION FOR HIGH-RISK CERVICAL CARCINOMA. INT J GYNECOL CANCER 1999;9:333-6.

20. Dueñas-GonzÁlez A, Verastegui E, López-Graniel C, ET AL. A PILOT STUDY OF PERILYMPHATIC LEUKOCYTE CYTOKINE MIXTURE (IRX2) AS NEOADJUVANT TREATMENT FOR EARLY STAGE CERVICAL CARCINOMA. INT IMMUNOPHARMACOL 2002;2:1007-16.

21. Dueñas-González A, González EA, López-Graniel C, ET AL. A PHASE II STUDY OF GEMCITABINE AND CISPLATIN COMBINATION AS INDUCTION CHEMOTHERAPY FOR UNTREATED LOCAlly adVANCED CERVical CARCinoma. ANN ONCOL 2001;12:541-7.

22. López-Graniel C, Reyes M, Chanona G, et al. Type III RADICAL HYSTERECTOMY AFTER INDUCTION CHEMOTHERAPY FOR PATIENTS WITH LOCALLY ADVANCED CERVICAL CARCINOMA. INT J GyNECOL CANCER 2001;11:210-7.

23. Dueñas-González A, Mota A, López-Graniel C, et al. THE ADVANTAgES OF CONCURRENT CHEMORADIATION AFTER NEOADJUVANT CHEMOTHERAPY FOR LOCALLY ADVANced cervical carcinoma. Arch Med Res 2002;33:201-2.

24. Dueñas-González A, López-Graniel C, González AE, ET AL. INDUCTION CHEMOTHERAPY WITH GEMCITABINE AND OXALIPLATIN FOR LOCALLY ADVANCED CERVICAL CARCINOMa. Am J CLIN ONCOL. In PRESS.

25. Benedetti-Panici P, Greggi S, Colombo A, et al. NeoADJUVANT CHEMOTHERAPY AND RADICAL SURGERY VERSUS EXCLUSIVE RADIOTHERAPY IN LOCALLY ADVANCED SQUAMOUS CELL CERVICAL CANCER. RESULTS FROM THE ITALIAN Multicenter Randomized Trial. J Clin Oncol 2002,20:179-88.

26. Dueñas-González A, López-Graniel C, González-Enciso A, ET AL. Concomitant CHEMORADiation VERSUS NEOADJUVANT CHEMOTHERAPY IN LOCALLY ADVANCED CERVICAL CARCINOMA. Results from tWo COnSECutive PHASE II TRIALS. ANN ONCOL 2002;13:1212-9.

27. Dueñas-González A, López-Graniel CM, Mota A, MohaR A. NEOADJUVANT CHEMOTHERAPY FOLLOWED BY SURGERY IN LOCALLY ADVANCED CERVICAL CARCINOMA [LETTER]. J CLIN ONCOL 2002;20:2908-9.

28. Patricia Hernández P, Primitivo Olivera P, Alfonso Dueñas-González A, ET AL. Gemcitabine aCtivity in cervical cancer cell lines. Cancer Chemother PharmaCOL 2001;48: 4,88-92.

29. Zarba J, Jaremtchuk A, Cendro M, et al. A phase I-II STUDY OF WEEKLY CISPLATIN AND GEMCITABINE WITH CONCURRENT RADIOTEHRAPY IN LOCALLY ADVANCED CERVICal cancer (abstract 822). Procc ASCO 2001;20:206A.

A. Dueñas-GonZÁLEZ Unidad de Investigación Biomédica en CÁNCER. InSTITUTO DE INVESTIGACIONES BiomÉDiCAS, UNAM e Instituto Nacional de Cancerología. México 